\title{
WACKERNAGEL'S POSITION AND CONTACT POSITION OF PRONOMINAL ENCLITICS IN OLDER CZECH. COMPETITION OR COOPERATION?
}

\author{
RADEK ČECH ${ }^{1}$ - PAVEL KOSEK ${ }^{2}$ - OLGA NAVRÁTILOVÁ ${ }^{2}$ - JÁN MAČUTEK ${ }^{2,3}$ \\ ${ }^{1}$ University of Ostrava, Ostrava, Czech Republic \\ ${ }^{2}$ Masaryk University, Brno, Czech Republic \\ ${ }^{3}$ Comenius University, Bratislava, Slovakia
}

\begin{abstract}
ČECH, Radek - KOSEK, Pavel - NAVRÁTILOVÁ, Olga - MAČUTEK, Ján: Wackernagel's position and contact position of pronominal enclitics in Older Czech. Competition or Cooperation? Journal of Linguistics, 2019, Vol. 70, No 2, pp. 267 - 275.
\end{abstract}

\begin{abstract}
The paper focuses on analyzing the relationship among word order positions of pronominal enclitics in the history of Czech. Specifically, we look at the Wackernagel's position and the contact position and we try to decide whether these two positions compete, as usually taken for granted, or whether there is a certain kind of cooperation between them. The results show that the positions do not compete, at least not in the majority of cases. We used a corpus-based on selected books of the first edition of the Old Czech Bible and Kralice Bible for the analysis.
\end{abstract}

Keywords: corpus linguistics, corpus lexicography, dialect corpora

\section{INTRODUCTION}

This article focuses on analyzing the word order of older Czech pronominal enclitics dependent on a finite verb in the corpus of selected books from a) the younger copies of the first edition of the Old Czech Bible - Olomouc Bible (Bible olomoucká) and the Litoměřice-Třeboň Bible (Bible litoměřicko-třeboňská) - and b) from the Kralice Bible (Bible Kralická). Previous research ([1], [2], [3]) shows that the word order of the older Czech pronominal (and auxiliary) enclitics follows one of the two main patterns: 1. the pronominal enclitic is in the Wackernagel's position (also called the post-initial position), i.e. the second position in a clause, the example (1) demonstrates this pattern for the enclitic pronominal form $m i$ 'to me', 2 . the pronominal enclitic is in the contact position, i.e. in the position that is in the immediate vicinity of its superordinate verb, its governor (hence, also called verbadjacent position). This pattern is demonstrated in the example (2): ${ }^{1}$

${ }^{1}$ Both word-order patterns occur in texts of various stages in the historical development of Czech in several variants: 1 . the second position differs between the position of the pronominal enclitic after the first phrase of a clause and the position after the first word of the first phrase of a clause, 2. the contact position 
(1) $\mathrm{a}[\mid$ Kto mi toho pojič́i, | [aby byly popsány řěči mé?]]

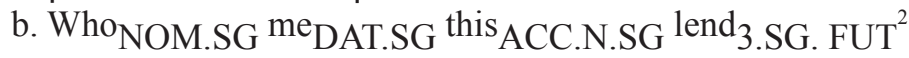

BiblOl Jb 19,23

(2) a. Hospodin bóh otevř̌̆l mi jest ucho...

b. Lord NOM.M.SG God NOM.M.SG open PTCP.PST.M.SG me ${ }_{\text {DAT.SG }}$

be AUX.PRS.3.SG ${ }^{\text {ear ACC.N.SG }}$

BiblOl Isa 50,5

Both word-order patterns (positions) exist in modern Slavic languages [4], so that the situation of older Czech - showing the same variation - is relevant for research of contemporary Slavic languages as well.

Although enclitics are considered to be a group of heterogeneous language units $[5,6]$, they share some common characteristics (at least stochastic ones) manifested in their phonological and syntactic behavior. First, they are prosodically deficit, i.e. they bear no word stress, and, consequently, they are prosodically joined with the preceding word. Moreover, they have a strong tendency to appear in the second position in a clause and that is true for various languages. This is the wellknown Wackernagel's position (also marked 2P in the following text) [7]. In the second position pattern, enclitic's syntactic governor does not have to be the same word that the enclitic is prosodically joined with. Thus, both prosodic and syntactic properties (and their interplay) influence enclitics' word order.

According to the well-accepted assumption, the Wackernagel's position is the original position of enclitics in Indo-European languages and, hence, also a common linguistic pattern in Proto-Slavic. The emergence of the contact position in the historical development of the Slavic languages has been interpreted as a manifestation of the grammaticalization process that transformed enclitics to inflectional affixes [8], cf. Russian он смеялся, where the original enclitic $с я$ is a non-separable part (morpheme) of the word.

Pancheva [9] suggests that the word order of these language units and the development of their positions is more complex. First, she shows that we need a more detailed classification of particular positions in order to understand this phenomenon properly. Second, her analysis of the Old Bulgarian examples challenges the general view on the grammaticalization process substantially. Similarly, ([2], [10]) discussed other factors that influence the word order of enclitics (especially the possible variations in both the second and contact positions) in older

differs between the position of the pronominal enclitic after its governor (postverbal position) and the position of the pronominal enclitic before its governor (preverbal position). For more details, see [1], [2], [3].

${ }^{2}$ To translate the Old Czech examples completely would lengthen this paper unacceptably; hence, we only cite one example for each phenomenon and a gloss is given just for the relevant part of the example (the glossed parts of the example are indicated by a vertical line $\mid$ ). 
Czech systematically (concerning style, length of the initial phrase, etc.). To sum up, these studies show that the problem requires further discussion.

However, there is an essential problem of the word order of enclitics, and that is the relationship between the Wackernagel's and contact patterns. As alluded to above, the relationship has not been analyzed fully yet in neither of the above-mentioned works. From recent studies, one might get an impression that the $2 \mathrm{P}$ and the contact position are result of different mechanisms, that, somehow, seem to compete with each other. However, the syntactically superior element (the enclitic's governor) can occur in the first and the third position in a clause, i.e. in a position adjacent to the enclitic. In this case, there is no competition between these two positions - if anything, we might talk about cooperation. To our great surprise, there is no detailed analysis of this phenomenon (except [9], where the problem is mentioned, but not analyzed thoroughly). We see the problem as crucial for the following reasons. A finer classification of the elements involved in the $2 \mathrm{P}$ position could shed light on the principles behind the Wackernagel's law. For instance, if - in majority of cases - an enclitic falls into the $2 \mathrm{P}$ and this position is also the contact position, then it means that the law influences not only the enclitic position, but also the position of the clitic's governor. Alternatively, the position of the syntactic governor can play a more important role than usually assumed even in the case the enclitic is in the $2 \mathrm{P}$. More generally, it is possible to consider this problem as an instance of the least effort principle [11]. In any case, we need better empirical evidence, so that we can gain more substantial insight into the problem. Therefore, in this study, we analyze the relationship between the $2 \mathrm{P}$ and the contact position of the enclitic in Older Czech.

Our aim is to observe whether their relationship is competitive, cooperative or neutral (for details see Section 2). Older Czech is chosen intentionally for the following reasons: a) there is a variability of word order (cf. [1], [2], [3]), especially if compared to the contemporary Czech (the relative rigidity of clitic placement in the contemporary Czech might be sought in linguistic prescription established in the middle of the $20^{\text {th }}$ century); b) we chose texts that represent both the oldest period (14 $4^{\text {th }}$ century) and younger period $\left(16^{\text {th }}\right.$ century) with enough language material available for linguistic research. Thus, it is a proper starting point for modeling the historical development of this phenomenon.

\section{LANGUAGE MATERIAL AND METHODOLOGY}

We chose two Czech Bible editions translated in different periods and from different pretexts: 1 . The first edition of the Old Czech Bible ( $2^{\text {nd }}$ half of $14^{\text {th }}$ century), 2. Kralice Bible ${ }^{3}$ (1579-1594). This material was chosen for the following reasons:

${ }^{3}$ This Bible was highly valued for its brilliant language and it was re-printed repeatedly. It also served as a model (and an unattainable) ideal for the Modern Czech codification in the $19^{\text {th }}$ century. 
1. The first edition represents one of the oldest Old Czech prose texts ${ }^{4}$ (original Czech texts from an earlier stages are not suitable for the word-order analysis: it is poetry). 2. In our view, the diachronic perspective desired for our research is best brought by comparison of two different historical translations of similar texts. The texts are similar, but crucially, they are not the same: a) the first edition of the Old Czech Bible and Kralice Bible were translated by different translators, b) the first edition of the Old Czech Bible was translated from the Middle Age Latin Vulgata, ${ }^{5}$ whereas the Kralice Bible was translated by the members of the Unity of the Brethren (Jednota bratrská) from the Latin and Greek pretexts (New Testament) and Hebrew and Latin pretexts (Old Testament). ${ }^{6}$

Since the language material must be annotated manually, we restricted ourselves to the selected books both from the Old and New Testament. Intentionally, we selected texts with different styles and structure, as well as texts by different translators: The Gospels of Matthew and Luke, the Acts of the Apostles, the Revelation of John from the New Testament and Genesis, Job, Sirach, and Isaiah (chapters 14 to 66) from the Old Testament. For compiling this transcribed corpus, we used 1. the modern edition of the Olomouc and Litomerrice-Třeboň Bible, i.e. the younger copies (from the beginning of $15^{\text {th }}$ century) of the original Old Czech translation (the original itself has not been preserved) [15], [16], [17], [18], [19], 2. the first edition of the Kralice Bible (1579-1594).

To observe "competition" and/or "cooperation" of the two possible word order patterns of enclitics, the language material is annotated as follows. We determine

a) The postinitial contact position (2PC position). In this case, the enclitic (E) occurs right after the initial phrase which is its governor $(\mathrm{G})$, schematically

(3) $[\mathrm{G}][\mathrm{E}][]^{*}$

(the symbol []* represents zero or more syntactic units of the clause)

or the enclitic (E) occurs after the initial phrase of any type, except its governor ([]) and the enclitic is immediately followed by its governor (G), schematically

(4) []$[\mathrm{E}][\mathrm{G}][]^{*}$

b) The post-initial isolated position (2PI position). In this case, the enclitic (E) occurs after the initial phrase of any clausal element type except its governor ([]) and it is followed by one or more syntactic element(s) of any clausal element type except its governor $([]+)$, schematically

(5) []$[\mathrm{E}][]+[\mathrm{G}][]^{*}$

\footnotetext{
${ }^{4}$ From the philological perspective, the language of the Bible is discussed in [12].

${ }^{5}$ For details, see [13].

${ }^{6}$ For details, see [14].
} 
c) The non-post-initial contact position (NPC position). In this case, the enclitic (E) occurs anywhere except in the post-initial position and it is adjacent to its governor, schematically

(6) [][]$+[E][G][]^{*}$

or

(7) []$+[\mathrm{G}][\mathrm{E}][]^{*}$

d) The non-post-initial isolated position (NPI position). In this case, the enclitic (E) occurs anywhere except in the post-initial position and it is not adjacent to its governor, schematically

(8) [][]$+[\mathrm{E}][]+[\mathrm{G}][]^{*}$

or

(9) []$^{*}[\mathrm{G}][]^{+}+[\mathrm{E}][]^{*}$

It should be noted that the example (9) was not attested in Slavic languages [4] and should be considered ungrammatical.

The distribution of these positions is examined on the pronominal form $m i$ 'to me'. This form was a permanent enclitic already in Proto-Slavic and appears with sufficient frequency in the analyzed biblical texts. The other pronominal forms are either not documented at all $s i, t i$ 'to myself / to yourself etc., to you', or documented in just a few examples ho, mu 'him, to him', or are not used at all for different reasons; š̌, tě 'myself / yourself etc., you', for instance, could sometimes bear stress and could be used after prepositions.

Frequency of particular positions in the corpora was observed and their proportions were counted. The results are to be interpreted in the following way: a) the prevalence of the $2 \mathrm{PC}$ position suggests that there is a cooperation between mechanisms leading to the Wackernagel's position and the contact position; $b$ ) the prevalence of the 2PI position means that the Wackernagel's law is dominant and it is in competition with the contact position; c) the prevalence of the NPC position should be interpreted so that the contact position is dominant and it is in competition with the Wackernagel's law, d) the prevalence of the NPI position means that neither the Wackernagel's law nor the contact position influence the word order of the enclitics in any way.

\section{RESULTS}

The absolute and relative frequencies of particular positions are shown in Table 1, 2 and Figure 1. 


\begin{tabular}{|c|c|c|c|c|c|}
\hline & $2 \mathrm{PC}$ & 2PI & NPC & NPI & $\sum$ \\
\hline Gn & 83 & 14 & 11 & 0 & 108 \\
\hline$\%$ & 76.85 & 12.96 & 10.19 & 0 & \\
\hline $\mathrm{Jb}$ & 33 & 4 & 3 & 1 & 41 \\
\hline$\%$ & 80.49 & 9.76 & 7.32 & 2.44 & \\
\hline Ecc & 8 & 2 & 2 & 0 & 12 \\
\hline$\%$ & 66.67 & 16.67 & 16.67 & 0 & \\
\hline $\mathrm{Iz}$ & 7 & 0 & 4 & 0 & 11 \\
\hline$\%$ & 63.64 & 0.00 & 36.36 & 0 & \\
\hline $\mathrm{Mt}$ & 22 & 6 & 0 & 0 & 28 \\
\hline$\%$ & 78.57 & 21.43 & 0 & 0 & \\
\hline Lk & 19 & 2 & 1 & 0 & 22 \\
\hline$\%$ & 86.36 & 9.09 & 4.55 & 0 & \\
\hline Sk & 26 & 1 & 1 & 0 & 28 \\
\hline$\%$ & 92.86 & 3.57 & 3.57 & 0 & \\
\hline $\mathrm{Zj}$ & 11 & 2 & 1 & 0 & 14 \\
\hline$\%$ & 78.57 & 14.29 & 7.14 & 0 & \\
\hline$\sum$ & 209 & 31 & 23 & 1 & 264 \\
\hline$\%$ & 79.17 & 11.74 & 8.71 & 0.38 & \\
\hline
\end{tabular}

Tab. 1. Absolute and relative frequencies of particular positions in the Olomouc Bible

\begin{tabular}{|l|r|r|r|r|r|}
\hline & $2 \mathrm{PC}$ & $2 \mathrm{PI}$ & NPC & NPI & $\sum$ \\
\hline $\mathrm{Gn}$ & 74 & 12 & 16 & 1 & 103 \\
\hline$\%$ & 71.84 & 11.65 & 15.53 & 0.97 & \\
\hline $\mathrm{Jb}$ & 32 & 7 & 9 & 0 & 48 \\
\hline$\%$ & 66.67 & 14.58 & 18.75 & 0.00 & 12 \\
\hline $\mathrm{Ecc}$ & 8 & 2 & 2 & 0 & 39 \\
\hline$\%$ & 66.67 & 16.67 & 16.67 & 0.00 & 31 \\
\hline $\mathrm{Iz}$ & 25 & 4 & 10 & 0 & 23 \\
\hline$\%$ & 64.10 & 10.26 & 25.64 & 0.00 & \\
\hline $\mathrm{Mt}$ & 25 & 4 & 2 & 0 & \\
\hline$\%$ & 80.65 & 12.90 & 6.45 & 0.00 & 0 \\
\hline $\mathrm{Lk}$ & 15 & 3 & 5 & 0.00 & \\
\hline$\%$ & 65.22 & 13.04 & 21.74 & 0.00 & \\
\hline
\end{tabular}




\begin{tabular}{|l|r|r|r|r|r|}
\hline & $2 \mathrm{PC}$ & $2 \mathrm{PI}$ & $\mathrm{NPC}$ & NPI & $\sum$ \\
\hline $\mathrm{Sk}$ & 21 & 5 & 4 & 1 & 31 \\
\hline$\%$ & 67.74 & 16.13 & 12.90 & 3.23 & \\
\hline $\mathrm{Zj}$ & 22 & 1 & 2 & 0 & 25 \\
\hline$\%$ & 88.00 & 4.00 & 8.00 & 0.00 & \\
\hline$\sum$ & 222 & 38 & 50 & 2 & 312 \\
\hline$\%$ & 71.15 & 12.18 & 16.03 & 0.64 & \\
\hline
\end{tabular}

Tab. 2. Absolute and relative frequencies of particular positions in the Kralice Bible

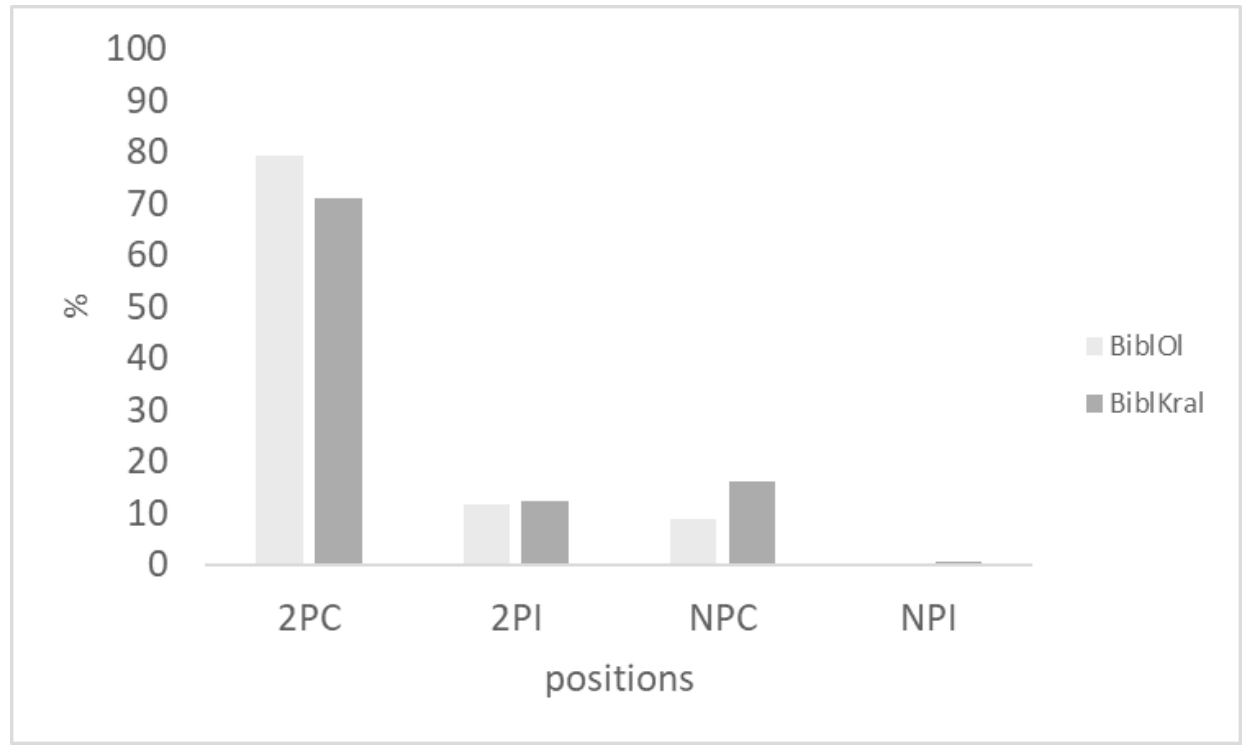

Fig. 1. Relative frequencies of particular positions in the Olomouc Bible (BiblOl) and the Kralice Bible (BiblKral)

The results show that the $2 \mathrm{PC}$ position is clearly dominant in all the cases. It means that the Wackernagel's position and the contact position are not in competition in the majority of cases. Furthermore, this result is not influenced by the style of the pretext or the translation. Moreover, a comparison of the Olomouc Bible and the Kralice Bible shows the same tendency in both corpora. Even though there are some differences (a higher proportion of the NPC position accompanied with a lower proportion of the $2 \mathrm{PC}$ position in the Kralice Bible), the application of simulate chisquare test reveals that the result is on the border of significant difference (for the significance level $\alpha=0.05$ ), $\chi 2=7.47$, $p$-value $=0.058$. This means that despite a) the time span of 200 years, b) the different pretexts, and c) different translation "strategy" [14], we identify a stable language behavior for the clitic placement phenomenon. 
As for the 2PI and the NPC positions, the differences in their proportions in various biblical books are striking. However, absolute frequencies are too small, thus, it would be wrong to interpret these results. Nevertheless, the above-mentioned higher proportion of the NPC position in the Kralice Bible (for all the books in the corpus), can be interpreted as pointing towards an increasing competition between these two positions. However, only further research can reveal whether it is a manifestation of the historical development, or specificity of the translators of the Kralice Bible, or, eventually, whether it is only a random fluctuation (cf. above-mentioned result of the statistical test). Finally, the minimal frequency of the NPI position shows that there had been a very strong tendency to avoid such word order patterns that do not follow the main enclitic placement strategies, i.e. in the Wackernagel's and/or the contact position (even if the position might be grammatical).

\title{
4 CONCLUSION
}

Our results show that the word order of the selected Czech enclitic pronominal form $m i$ ' $m e$ ' in the chosen two historical Czech Bibles is by and large limited to the two dominant word-order patterns: the Wackernagel's position and the contact position. Surprisingly, these two positions do not compete with each other but rather cooperate: most examples in our study are clauses in which the post-initial and the contact position of an enclitic merge. A question that requires further research is whether this situation is specific to the language of biblical translation or whether it manifests a general mechanism and, further, whether this situation has changed during the following development of Czech.

\section{ACKNOWLEDGMENTS}

This study was supported by the project Development of the Czech pronominal (en)clitics (GAČR GA17-02545S).

\author{
References
}

[1] Kosek, P., Navrátilová, O., and Čech, R. (2018). Slovosled staročeských pronominálních enklitik závislých na VF ve staročeské bibli 1. redakce. SLAVIA časopis pro slovanskou filologii, 87(13), pages 189-204.

[2] Kosek, P., Navrátilová, O., Čech, R., and Mačutek, J. (2018). Word Order of Reflexive 'sě' in Finite Verb Phrases in the First Edition of the Old Czech Bible Translation. (Part 2). Studia Linguistica Universitatis Iagellonicae Cracoviensis, 135(3), pages 189-200.

[3] Kosek, P., Čech, R., and Navrátilová, O. (2018). Starobylá dativní enklitika mi, si, ti ve staročeské bibli 1. redakce. In Malčík, P. (ed.). Vesper Slavicus. Sborník k nedožitým devadesátinám prof. Radoslava Večerky. Studia etymologica Brunensia 23, Praha, Nakladatelství Lidové noviny, pages 137-151. 
[4] Franks, S., and King, T. H. (2000). A Handbook of Slavic Clitics. Oxford.

[5] Zwicky A. M. (1994). What is a Clitic. In Nevis, J. A., Joseph B. D. et al. (eds.), Clitics. A Comprehensive Bibliography 1892-1991, pages 12-20.

[6] Uhlířová, L., Kosta, P., and Veselovská, L. (2017). Klitika. In Karlík, P., Nekula, M., Pleskalová, J. (eds.): Nový encyklopedický slovník češtiny.

[7] Wackernagel, J. (1892). Über ein Gesetz der indogermanischen Wortstellung. IF 1, pages 33-436.

[8] Zwicky, A. (1977). On Clitics. Bloomington, Indiana University Linguistics Club.

[9] Pancheva, R. (2005). The Rise and Fall of Second-position Clitics. Natural Language \& Linguistic Theory, 23, pages 103-167.

[10] Čech, R., Kosek, P., Navrátilová, O., and Mačutek, J. On the impact of the initial phrase length on the position of enclitics in the Old Czech. (to appear)

[11] Zipf, G. K. (1949). Human Behavior and the Principle of Least Effort. Cambridge, AddisonWesley.

[12] Kosek, P., Navrátilová, O., Čech, R., and Mačutek, J. (2018). Word Order of Reflexive 'sě' in Finite Verb Phrases in the First Edition of the Old Czech Bible Translation. (Part 1). Studia Linguistica Universitatis Iagellonicae Cracoviensis, 135(3), pages 177-188.

[13] Kyas, V. (1997). Česká Bible v dějinách národního písemnictví. Vyšehrad.

[14] Dittmann, R. (2012). Dynamika textu Kralické bible včeské překladatelské tradici. Refugium Velehrad-Roma.

[15] Kyas, V. (ed.). (1981). Staročeská bible drážd’anská a olomoucká: kritické vydání nejstaršího českého překladu bible ze 14. století. I. Evangelia. Praha.

[16] Kyas, V. (ed.). (1985). Staročeská bible drážd’anská a olomoucká: kritické vydání nejstaršího českého překladu bible ze 14. století s částmi Bible litoměřicko-třeboňské. II. Epištoly. Skutky apoštolů. Apokalypsa. Praha.

[17] Kyas, V. (ed.). (1988). Staročeská bible drážd’anská a olomoucká: kritické vydání nejstaršího českého překladu bible ze 14. století. III. Genesis - Esdráš. Praha.

[18] Kyas, V., Kyasová, V., and Pečírková, J. (eds.). (1996). Staročeská bible drážd’anská a olomoucká: kritické vydání nejstaršího českého překladu bible ze 14. století. IV. Tobiáš Sirachovec. Padeborn.

[19] Pečírková, J. (ed.). (2009). Staročeská Bible drážd’anská a olomoucká s částmi Proroků rožmberských a Bible litoměřicko-třeboňské, V/1 Izaiáš - Daniel, V/2 Ozeáš - 2. kniha Makabejská. Praha. 